\title{
An Error Analysis of English Monophthongs Pronunciation in Speaking
}

\author{
Muhyiddin Aziz ${ }^{1}$, Titik Rahayu ${ }^{2}$, Ita Permatasari ${ }^{3}$, Moh. Farid Maftuh $^{4}$, Ridho Muarief ${ }^{5}$ \\ Politeknik Negeri Madiun, Madiun East Java Indonesia ${ }^{1,2,3,4,5}$ \\ \{muhyiddinaziz@pnm.ac.id. ${ }^{1}$ \}
}

\begin{abstract}
Pronunciation is the most important aspect in communication. Error English pronunciations lead misunderstanding in communication. Thus, the researcher did the analysis to know the pronunciation errors of English monophthongs. The research's aims are: (1) to know the kinds of mispronounced monophthongs in English for the 2nd semester students of B class at Politeknik Negeri Madiun, English study program, in the academic year of 2019/2020, and (2) to know the causes of the mispronounced monophthongs in English for the 2nd semester students of B class at Politeknik Negeri Madiun, English Study Program, in the academic year of 2019/2020. The researcher used mixed method research. The qualitative and quantitative data were used in this research. The quantitative data were based on the errors of the students on the test and the qualitative data were based on the observations and interviews during the research. This research resulted that the most commonly error monophthongs are $/ \mathrm{i} /=36,4 \%, / \Lambda /=17,9 \%, / \mathrm{e} /=13,6 \%, / \mathfrak{m} /=12,1 \% / \mho /=11,4 \%$, and $/ \mathrm{a} /=8,6 \%$. The errors happened in the three classification such as substitution $=$ $72,1 \%$, insertion $=16,4 \%$, and omission $=11,5 \%$. The errors were caused by the inter-lingual and intra-lingual transfer determined by the students understanding in pronunciation, and influenced by the students first language and mother tongue.
\end{abstract}

Keywords: Error Analysis, Monophthongs, Pronunciation, Speaking English

\section{Introduction}

There are two ways in communication such as writing and speaking. In writing, the format and spelling become the most important parts to avoid miscommunication. In speaking, the pronunciation is the determiner. On the other hand, pronouncing English as foreign language is not easy. It is difficult to pronounce as the writing and the pronunciation are totally different. The spelling also cannot become the guide to pronounce it correctly. It happened to almost the students of B class as foreign language learners. Brown says that pronunciation is the key to gaining full communicative competence. In short, pronouncing English words are unpredictable and an important part of English. The different pronunciations or different sounds cause different meanings [1].

Speaking without considering the pronunciation causes misunderstanding in the meaning of the words spoken because pronunciation is one of the most fatal parts of communication in 
English. The mispronounced words determine the meaning. Harmer states that for all people, being made aware of pronunciation issues will be of immense benefit not only to their own pronunciation but also their understanding of spoken English [2]. Celce-Mursia and Goodwin state that pronunciation is the crucial parts to minimize misunderstanding in communication. It is considered as the requirement of speaking and listening skill development. Therefore, English communication requires some indicators such as knowing the meaning, understanding the used of the structure, and being able to use the phonetic transcription to pronounce English words in communication in order to communicate correctly and fluently with others [3][4].

Pronunciation is one of the important parts in English communication as it determines the change of the words meaning. Thus, It is completed by many important parts in English such as vowels, consonant, and phonetic transcription. Vowels are classified into three kinds namely pure vowels (monophthongs), diphthongs and triphthongs. There are twelve

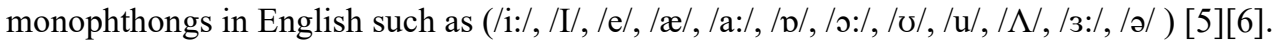

Furthermore, English pronunciation is different from Indonesian. English is always pronounced based on the phonetic transcription. It is not pronounced based on the writing or text itself. On the contrary, Indonesian is pronounced based on its writing or text. Besides, the accent of the two languages is different. Many English students especially at English study program of Politeknik Negeri Madiun. It happened on the $2^{\text {nd }}$ semester of B Class. They often make mistakes in pronunciation during the speaking class. They make mistakes on pronouncing the English words as they seldom check their vocabularies to the phonetic transcription in the dictionary. They also often make the errors on the length or short of vowels especially on monophthongs or pure vowels. They seem often being influenced by the Indonesian accent when they speak English. Besides, some students often did errors on substitution, insertion, and omission when they describe the tourism object during the test. For instance: Some students pronounce the word invite /invait/ become /infit/. It is classified as substitution error. The other students pronounce the word studied $/ \mathrm{st} \Lambda \mathrm{did} / \mathrm{become} / \mathrm{st} \Lambda \mathrm{di} \mathrm{d} /$. It is classified as insertion. The rest students pronounce the word develop /də'veləp/ become /div'lop/. It is classified as omission. In English Speaking or communication the relation of spelling and pronunciation is very complicated as the spelling and the pronunciation are not the same so that it is helped by the phonetic transcription [7]-[9].

Derived from the background of the research, the specific research questions are as follows:

a) What kinds of monophthongs in English are mispronounced by the $2^{\text {nd }}$ semester of English study program students (B class) in the academic year of 2019/2020?

b) What are the causes of the mispronounced monophthongs in English for the $2^{\text {nd }}$ semester of English study program (B class) in the academic year of 2019/2020?

\section{Review of Literature}

Yates and Zielinski state that pronunciation refers to how we produce the sounds that we use to make meaning when we speak. It includes the particular consonants and vowels of a language (segments), aspects of speech beyond the level of the individual segments, such as stress, timing, rhythm, intonation, phrasing, (supra-segmental aspects), and how the voice is projected (voice quality) [10], [11].

Monophthongs are pure vowels that do not need to change the speech organ position through the vowels articulation duration. Pure vowels are formed by the movement of the tongue position in the mouth as it is classified into a single perceived auditory quality. The 
pure vowels are divided into 12 pure vowels consisting five long in duration and seven short in duration. Moreover, they are also divided into three classifications such as 4 front vowels, 3 central vowels, and 5 back vowels. These are the description of twelve pure vowels as follows [12][13]:

a) $/ \mathrm{i}: /$, it is classified as high front close vowel. It is long in duration of pronunciation.

b) $/ \mathrm{I} /$, it is classified as mid-high front half close vowel. It is short in duration of pronunciation.

c) $/ e /$, it is classified as mid front half close vowel. It is short in duration of pronunciation.

d) $/ \mathfrak{x} /$, it is classified as mid-low front half open vowel. It is short in duration of pronunciation.

e) $/ 3: /$, it is classified as mid-high central half close vowel. It is long in duration of pronunciation.

f) $/ \mathrm{/} /$, it is classified as mid central half open vowel. It is short in duration of pronunciation.

g) $/ \mathrm{N} /$, it is classified as mid-low central half open vowel. It is short in duration of pronunciation.

h) $/ \mathrm{u}: /$, it is classified as high back close vowel. It is long in duration of pronunciation.

i) $/ \mho /$, it is classified as mid-high back half close vowel. It is short in duration of pronunciation.

j) $/ \mathrm{s} / \mathrm{h}$, it is classified as mid-low back half open vowel. It is long in duration of pronunciation.

$\mathrm{k}) / \mathrm{p} /$, it is classified as mid-low back half open vowel. It is short in duration of pronunciation.

1) /a:/, it is classified as low back open vowel. It is long in duration of pronunciation.

In addition, the description and classification of English vowels or monophthongs are explained in detail through the vowels matrix published by http://englishspeaklikenative.com/resources/vowels-matrix/.

Table 1. Vowels Matrix

\begin{tabular}{|c|c|c|c|c|c|c|c|c|c|c|c|}
\hline \multirow[t]{2}{*}{ IPA } & \multicolumn{5}{|c|}{ POSITION } & \multicolumn{2}{|c|}{ LENGTH } & \multicolumn{2}{|c|}{$\begin{array}{l}\text { TENSE } \\
\text { NESS }\end{array}$} & \multicolumn{2}{|c|}{$\begin{array}{c}\text { ROUND } \\
\text { NESS } \\
\end{array}$} \\
\hline & Back & Front & Mid & High & Low & Short & Long & Lax & Tense & Rounded & unrounded \\
\hline /i:/ & & 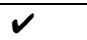 & & $\checkmark$ & & & $V$ & & $\nu$ & & $\checkmark$ \\
\hline /i/ & & $\nu$ & & $\nu$ & & $\checkmark$ & & $\boldsymbol{V}$ & & & $\nu$ \\
\hline /u:/ & $\checkmark$ & & & $\checkmark$ & & & $\checkmark$ & & 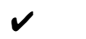 & 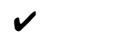 & \\
\hline$/ \mho /$ & $\nu$ & & & $\checkmark$ & & $\nu$ & & $\checkmark$ & & $\checkmark$ & \\
\hline$/ æ /$ & & $\checkmark$ & & & $\boldsymbol{V}$ & $\nu$ & $\checkmark$ & $\checkmark$ & & & $\checkmark$ \\
\hline /e/ & & $\nu$ & $\nu$ & & & $\nu$ & & $\checkmark$ & & & $\nu$ \\
\hline /a:/ & $\checkmark$ & & & & $\nu$ & & $\checkmark$ & $\checkmark$ & & $\nu$ & \\
\hline$/ \Lambda /$ & & & $\nu$ & & & $\checkmark$ & & $\checkmark$ & & & $\nu$ \\
\hline /3:/ & $\nu$ & & & & $\nu$ & & $\checkmark$ & $\checkmark$ & & $\boldsymbol{V}$ & \\
\hline$/ a /$ & & & $\checkmark$ & & & $\checkmark$ & & $\checkmark$ & & & $\boldsymbol{V}$ \\
\hline$/ \mathrm{p} /$ & & & $\checkmark$ & $\nu$ & & $\nu$ & & $\checkmark$ & & 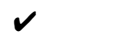 & \\
\hline /0:/ & $\checkmark$ & & & & $\nu$ & & $\checkmark$ & & 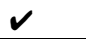 & $\checkmark$ & \\
\hline
\end{tabular}

\section{Research Methods}

There are two kinds of research method used by the researcher. They are qualitative and quantitative research method. The qualitative research method is formed by using interviews, 
words, and opened-end question. While quantitative is basically framed in term of using numbers and closed-end question [14].

Beside two basic research methods, Creswell also proposed another research approach, mixed methods research. It is a combination of two approach methods that is used to collect the qualitative and quantitative data and integrate them to get the comprehensive philosophical assumptions and theoretical frameworks. This combination provides more complete understanding.

The qualitative and quantitative data were used in this research. The students' errors pronouncing English monophthongs are classified into the quantitative data. The data were students' errors during the examination or test. states that documentation method is technique to find data about something and all variables that are classified into notes, transcript, books, photograph, video, voice recorder, epigraphy, notes of meeting, agendas etc. This first method focused on quantitative phase through spoken test by the following technique:

a) The Participants were given the spoken test.

b) The participants read aloud the text.

c) The researcher recorded participant's voice by using phone when he/she read the test.

d) Then, the researcher listened to the recorded pronunciation several times and transcribed them by using the phonetic symbol from the transcription.

Meanwhile there are some techniques were used to collect the qualitative data such as observations and interviews. This second method focused on qualitative phase through interview by using the following techniques:

a) The researcher asked the participants orally by structured interview questions after they finished conducted the spoken test, without turning off the recorder.

b) The researcher collected the recorded.

c) The researcher listened to the recorded.

d) The researcher transcribed the recorded into a written form.

After collecting the data, the next step were classifying the data and analysing the data. In analysing the data, the following techniques were conducted:

a) The researcher analysed the pronunciation of the students during the test.

b) The researcher made category the students' pronunciation based on the right and wrong pronunciation.

c) The researcher made percentage the students' pronunciation.

d) The researcher found the dominant error of the students' pronunciation produced by the students and the reason why they dominantly made their error.

e) The researcher wrote the conclusions and suggestions based on the data analysis.

f) The researcher employed the percentage descriptive analysis to count all errors by using a simple formula.

Then, the researcher analysed qualitative data with result of interviews. The qualitative data analysis can be classified into four such as coding the data, reducing the data, displaying the data, and drawing conclusion or interpretation.

\section{Research Results}

Pronunciation is one of the obligation lecture in english department as it gives large constribution to show that the students of English department have good quality in English. Everyone can directly know the students' skill at first based on what they speak and what they 
hear. Both of them are caused by the students' good understanding in theory and practise of pronunciotion.

In fact, many students of the second semester, B class, at English Department got difficulty to implement the theories that they got on the lecture. It is proved when they were examined by asking them to read the description of tourism places. As a result, they made mistake on pronouncing words.

Furthermore, the second semester students of B class got difficulty to pronouce some vowels on the classification of monophthongs with the classification of percentage as follows $/ \mathrm{i} /=36,4 \%, \quad / \mathrm{\Lambda} /=17,9 \%, \quad / \mathrm{e} /=13,6 \%, / \mathfrak{x} /=12,1 \% / \mathrm{\mho} /=11,4 \%$, and $/ \mathrm{\partial} /=8,6 \%$. They also got difficulty to differenciate the pronunciation of $\mathrm{e}$ and $æ$. The rest got problem on differenciationg the short and long vowels such as $v$, u:.

Table 2. Monophthong /i/

\begin{tabular}{cclll}
\hline No & Words & Errors & Correct Use & Occurrence \\
\hline 1 & Semester & /smestər/ & $/$ simestə(r)/ & 10 times \\
& & $/$ səmestər/ & & 7 times \\
2 & Department & $/$ dəp $\Lambda$ rtmən/ & $/$ dip $\Lambda$ rtmən/ & 5 times \\
3 & ticket & $/$ tikæt/ & $/$ tikit/ & 7 times \\
4 & Mountain & $/ /$ maunten/ & $/$ mauntin/ & 5 times \\
& & $/ /$ mauntn/ & & 6 times \\
& & $/$ 'mauntain/ & & 3 times \\
5 & Studied & $/$ st $\Lambda$ did/ & $/$ st $\Lambda$ diəd/ & 8 times \\
\hline
\end{tabular}

Table 3. Monophthong / $\Lambda$ /

\begin{tabular}{lllll}
\hline No & Words & Errors & Correct Use & Occurrence \\
\hline 1 & Study & $/$ stədi/ & $/$ st $\Lambda \mathrm{di} /$ & 5 times \\
2 & laugh & $/$ ləf/ & $/ 1 \Lambda \mathrm{f} /$ & 10 times \\
& & $/$ æf/ & & 3 times \\
3 & Luck & $/ \mathrm{læk} /$ & $/ 1 \Lambda \mathrm{k} /$ & 7 times \\
\hline
\end{tabular}

Table 4. Monophthong /e/

\begin{tabular}{lllll}
\hline No & Words & Errors & Correct Use & Occurrence \\
\hline 1 & bread & $/$ brid/ & /bred/ & 4 times \\
& & $/$ bræd/ & & 10 times \\
2 & Airport & $/$ ai(r)pot/ & $/ \mathrm{e}(\mathrm{r}) \mathrm{p}$ t/ & 5 times \\
\hline
\end{tabular}

Table 5. Monophthong /æ/

\begin{tabular}{|c|c|c|c|c|}
\hline No & Words & Errors & Correct Use & Occurrence \\
\hline 1 & Lamp & /ləmp/ & /læmp/ & 5 times \\
\hline 2 & $\mathrm{Bad}$ & /bed/ & /bæd/ & 8 times \\
\hline 3 & Lack & $/ 1 \Lambda \mathrm{k} /$ & /læk/ & 4 times \\
\hline \multicolumn{5}{|c|}{ Table 6. Monophthong / / } \\
\hline No & Words & Errors & Correct Use & Occurrence \\
\hline \multirow[t]{2}{*}{1} & put & $/$ pat/ & /pot/ & 3 times \\
\hline & & /pv:t/ & & 5 times \\
\hline \multirow[t]{2}{*}{2} & would & /wad/ & /wod/ & 1 times \\
\hline & & /wv:d/ & & 5 times \\
\hline
\end{tabular}


Table 7. Monophthong /a/

\begin{tabular}{lllll}
\hline No & Words & Errors & Correct Use & Occurrence \\
\hline 1 & Distance & /distæns/ & /distəns/ & 5 times \\
& & $/$ distens/ & & 3 times \\
2 & Ocean & $/$ oshen/ & $/$ oshən/ & 2 times \\
3 & Picture & $/$ pikt $\int \mathrm{e}(\mathrm{r}) /$ & $/ \mathrm{pikt} \partial(\mathrm{r}) /$ & 2 times \\
\hline
\end{tabular}

The second semester students of B class made some pronunciation errors that can be classified into three kinds by the researcher after being analyzed and distinguished. It happened during the examination when they described the tourism objects. The errors happened on monophthongs 140 occurrences with the three kinds of pronunciation errors classification such as substitution, insertion, and omission.

Table 8. The Percentage of Error

\begin{tabular}{llcc}
\hline No & Kinds Of Error & Occurrence & Percentage \\
\hline 1 & Substitution & 101 & $72,1 \%$ \\
2 & Insertion & 23 & $16,4 \%$ \\
3 & Omission & 16 & $11,5 \%$ \\
& Total & 140 & $100 \%$ \\
\hline
\end{tabular}

The causation of mispronounced words or error pronunciation can be classified into two categories such as inter-lingual and intra-lingual transfer. These two causation categories were found during teaching and testing the students' pronunciation during this research. It was also found the information from the students on the session of observation and interview during the class session. They said that English was difficult to pronounce and understanding one pronunciation cannot become the other words' characteristics of pronouncing them [15].

Inter-lingual transfer is a significant source for language learners. This research found that inter-lingual transfer contributed one of the causation of pronunciation errors occurred at the different level. The students made errors because they were still influenced by their first language and mother tongue as Indonesia has one first language but many mother tongues based on the regions they live. Then the causation of errors was followed by intra-lingual transfer. It was caused by the influence of one target language item upon another. The students said that learning English makes them confused. When they have understood about the spelling rule, but not all the words follow the spelling rule. They still do not understand about what they have learned. In short, every English word has its own phonetic transcription to read [16][12].

\section{Conclusion}

After conducting the research, the researcher can conclude that Indonesian students specifically the $2^{\text {nd }}$ semester students of English Study Program (B class) are classified into foreign language learners. So that it is reasonable to be classified as the potential persons to make errors whether in spoken or written language especially in pronunciation. In this research the $2^{\text {nd }}$ semester students of English Study Program produced many mistakes in pronouncing English monophthongs during the tests of the research in speaking class. The students made the errors of monophthongs such as $/ \mathrm{i} /=36,4 \%, / \Lambda /=17,9 \%, / \mathrm{e} /=13,6 \%$, $/ æ /=12,1 \% / \mho /=11,4 \%$, and $/ \mathrm{a} /=8,6 \%$ with the total occurrences 140 times. They had different 
percentages on the kinds of error classification such as substitution $72,1 \%$, insertion $16,4 \%$, and omission $11,5 \%$.

Some factors contributed to the student's errors in pronouncing English monophthongs. The research observation and interviews showed that in Indonesia English is addressed to foreign language as the first one is mother tongue and the second one is Indonesian. They also have limited time to practice English pronunciation as their environment does not support it. They also got difficulty to match the two differences of sound system between Indonesian and English or even with the mother tongue in which in Indonesia, every region has their own mother tongue with the different words and dialect.

Furthermore, there are also some reasons as the causation of pronunciation errors, that is, inter-lingual and intra-lingual transfer. These two causations happened because of the different factors of the students. The first factor is caused by the influence of the first language or even the mother tongue as it is called inter-lingual transfer. The second factor is caused by the students fault or partial learning of target language and it is called intra-lingual transfer $[3][11]$.

Table 9. Appendix A

The percentage of the occurrences

\begin{tabular}{|c|c|c|}
\hline Monophthongs & Occurance & Percentage \\
\hline /i/ & 51 & $36,4 \%$ \\
\hline /i:/ & 0 & $0 \%$ \\
\hline /e/ & 19 & $13,6 \%$ \\
\hline 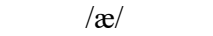 & 17 & $12,1 \%$ \\
\hline /a:/ & 0 & $0 \%$ \\
\hline$/ \mathrm{w} /$ & 0 & $0 \%$ \\
\hline /o:/ & 0 & $0 \%$ \\
\hline$/ \mathrm{J} /$ & 16 & $11,4 \%$ \\
\hline /u:/ & 0 & $0 \%$ \\
\hline$/ \Lambda /$ & 25 & $17,9 \%$ \\
\hline /3:/ & 0 & $0 \%$ \\
\hline /a/ & 12 & $8,6 \%$ \\
\hline Total & 140 & $100 \%$ \\
\hline
\end{tabular}

Table 10. Appendix B

The Percentage of error kinds

\begin{tabular}{|c|c|c|c|}
\hline Monophthongs & Substitution & Insertion & Omission \\
\hline /i/ & 24 & 11 & 16 \\
\hline /i:/ & 0 & 0 & 0 \\
\hline /e/ & 19 & 0 & 0 \\
\hline$/ \mathfrak{a} /$ & 17 & 0 & 0 \\
\hline /a:/ & 0 & 0 & 0 \\
\hline$/ \mathrm{w} /$ & 0 & 0 & 0 \\
\hline /o:/ & 0 & 0 & 0 \\
\hline$/ \mathrm{v} /$ & 4 & 12 & 0 \\
\hline /u:/ & 0 & 0 & 0 \\
\hline$/ \Lambda /$ & 25 & 0 & 0 \\
\hline /3:/ & 0 & 0 & 0 \\
\hline$/ 2 /$ & 12 & 0 & 0 \\
\hline Total & 101 & 23 & 16 \\
\hline Percentage & $72,1 \%$ & $16,4 \%$ & $11,5 \%$ \\
\hline
\end{tabular}




\section{Acknowledgements}

The researcher would like to thank the Director of Politeknik Negeri Madiun, vice directors, and the head of research unit of Politeknik Negeri Madiun that has supported and founded this research through DIPA Politeknik Negeri Madiun of the year 2020. The researcher also thanks to all lecturers as the team of research and the students that has helped and become the object of the research. The researcher thanks to Politeknik Negeri Madiun for the facilities given during the research. Lastly, the researcher thanks to my wife, Nita, and my children, Jauza \& Afa, who always support to finish the research and this article during the covid-19 pandemi.

\section{References}

[1] H.Douglas Brown, "[H._Douglas_Brown]_Teaching_by_Principles,_Second_(BookFi.org).pdf," Teaching by Principles An Interactive Approach to Language Pedagogy. p. 491, 2000.

[2] J. Harmer, "Chapter 6 (10).pdf." p. 138.

[3] M. Chang and J. S. Goswami, "Factors Affecting the Implementation of Communicative Language Teaching in Taiwanese College English Classes, " English Lang. Teach., vol. 4, no. 2, p. 3, 2011.

[4] S. Muawanah, "an Analysis of Pronunciation Errors of the Fourth Semester Students of Iain Surakarta in Drama Performance Entitled 'Nights Are Longer in Samarkand' in Academic Year 2014 / 2015 Islamic Education and Teacher Training Faculty,” 2017.

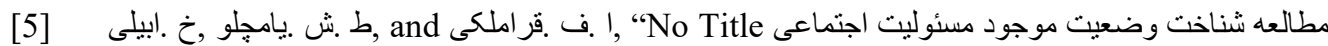

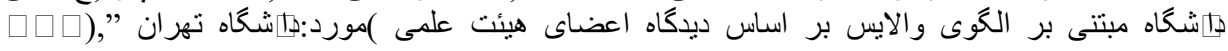

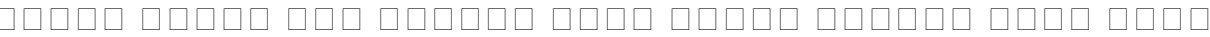
1396, $1395 \square \square \square \square \square \square \square \square \square \square \square \square$.

[6] A. S. Alghonaim, "Impact of Watching Cartoons on Pronunciation of a Child in an EFL Setting: A Comparative Study with Problematic Sounds of EFL Learners, ” Arab World English J., vol. 11, no. 1, pp. 52-68, 2020.

[7] R. Head, D. Mother, T. Affect, T. H. E. English, B. Pramjit, and S. Dhillon, "Running Head: DOES MOTHER TONGUE AFFECT THE ENGLISH PRONUNCIATION? 4 ICLEHI 2016-041 Bobby Pramjit Singh Dhillon, ” pp. 121-132, 2016.

[8] "Teaching_pronunciation_effectively." .

[9] Y. B. Ahmad, "Teaching English Pronunciation of Suprasegmental Features on Students of English Education," SHS Web Conf., vol. 42, p. 00048, 2018.

[10] L. Yates, "Learning how to speak: Pronunciation, pragmatics and practicalities in the classroom and beyond," Lang. Teach., vol. 50, no. 2, pp. 227-246, 2017.

[11] E. M. Clore-patron, "" Teaching Word Stress: A Curricular Resource For Adult English Language Learners At The High Beginner / Low Intermediate Levels ", " 2018.

[12] N. F. Andhini, 済無No Title No Title, vol. 53, no. 9. 2017.

[13] J. Padgett, “Glides, Vowels, and Features,” no. 1, pp. 1-22, 1996.

[14] J. W. Creswell and V. L. P. Clark, "Designing and Conducting Mixed Methods Research,” Aust. N. Z. J. Public Health, vol. 31, no. 4, pp. 388-388, 2007.

[15] L. N. Kartyastuti, "an Error Analysis in Pronunciation of English Vowels, ” 2017.

[16] A. H. A. Anni Holila Pulungan, "Pronunciation Errors in Speaking Performance of 
Grade 11 Students At Sma Negeri 20 Medan," Regist. J. English Lang. Teach. FBSUnimed, vol. 7, no. 2, 2018. 